\title{
Improved Bioassay of Xylella fastidiosa Using Nicotiana tabacum Cultivar SR1
}

\author{
M. Francis, University of California, Department of Plant Pathology, Davis 95616; E. L. Civerolo, United States \\ Department of Agriculture-Agricultural Research Service, San Joaquin Valley Agricultural Sciences Center, Parlier, \\ CA 93648; and G. Bruening, University of California, Department of Plant Pathology, Davis
}

\begin{abstract}
Francis, M., Civerolo, E. L., and Bruening, G. 2008. Improved bioassay of Xylella fastidiosa strains using Nicotiana tabacum cultivar SR1. Plant Dis. 92:14-20.

Readily transformable Nicotiana tabacum cv. SR1 (Petite Havana) was evaluated as a host for the bioassay of Xylella fastidiosa strains. Plant growing conditions and inoculation methods were optimized to enhance symptom expression 4 to 6 weeks post inoculation. Tobacco plants were inoculated with $X$. fastidiosa strains associated with almond leaf scorch disease (ALSD) and Pierce's disease (PD) of grapevine in California. All PD strains and the ALSD strain Dixon caused characteristic leaf scorch symptoms, whereas two other ALSD-associated strains (M12 and M23) caused severe leaf chlorosis followed by necrosis, leaf death, and drooping of older leaves. Symptoms began to develop 10 to 14 days post inoculation and proceeded to resemble those of $X$. fastidiosa-infected grape and almond. The presence of $X$. fastidiosa in affected plants was confirmed by reisolation of the pathogen, enzyme-linked immunosorbent assay, quantitative polymerase chain reaction (QPCR), and observation of $X$. fastidiosa cells by transmission and scanning electron microscopy, as well as by confocal laser scanning microscopy, in the xylem cells of inoculated plants. The pathogenicity of selected reisolated strains was confirmed by inoculation of grape plants in the greenhouse. The average levels of $X$. fastidiosa cells/g of tissue, estimated by QPCR, were higher for PD strains than for ALSD strains and reflected the relative titers of these strains in economic hosts. No symptoms were observed and bacteria were not detected in untreated tobacco or in tobacco inoculated with Xanthomonas campestris pv. campestris or water. Symptoms induced by Xylella fastidiosa in this bioassay were fully expressed within 2 months following inoculation. The described bioassay, under optimized environmental conditions, provides a useful system for studying $X$. fastidiosa strains (e.g., confirmation of pathogenicity and differentiation of PD and ALSD pathotypes) and for investigating $X$. fastidiosa-host interactions. $N$. tabacum cv. SR1 tobacco was a better bioassay host for X. fastidiosa than N. tabacum cvs. Havana, RP1, and TNN described previously.
\end{abstract}

Additional keywords: diagnosis, quantitative PCR

Xylella fastidiosa (25) causes economically important diseases of several agronomic and horticultural crops in North and South America, including alfalfa dwarf, Pierce's disease (PD) of grapevine, citrus variegated chlorosis (CVC), coffee leaf scorch, phony peach, pear leaf scald, pecan leaf scorch, almond leaf scorch, and plum leaf scald $(13,23)$, as well as leaf scorch of several landscape trees and ornamental plants (8). X. fastidiosa-caused diseases

Corresponding author: E. L. Civerolo

E-mail: eciverolo@fresno.ars.usda.gov

Current address of M. Francis: University of Florida, Citrus Research and Education Center, 700 Experiment Station Road, Lake Alfred 33850-2299.

Accepted for publication 7 September 2007.

doi:10.1094/PDIS-92-1-0014

This article is in the public domain and not copyrightable. It may be freely reprinted with customary crediting of the source. The American Phytopathological Society, 2008. have become increasingly important as serious threats to the production of several crops $(13,16,23)$. At the present time, disease diagnosis is based on the isolation of the bacterial pathogen and identification of the pathogen by enzyme-linked immunosorbent assay (ELISA) and polymerase chain reaction (PCR) and confirmation by inoculation of a susceptible host.

Previous attempts to use Nicotiana tabacum genotypes as experimental hosts for studying $X$. fastidiosa-plant interactions were based on inoculation with $X$. fastidiosa strains that cause CVC in Brazil $(3,17)$. The tobacco genotype initially used was a native variety of $N$. tabacum accession RP1, and symptoms consisted of orange lesions that did not appear until 2 months after inoculation. In addition, more than one inoculation was necessary for symptom development (17). Subsequently, tobacco cv. Havana was reported to express more intense symptoms than cv. TNN (3). Symptoms on cv. Havana consisted of wilting, yellowing, premature flowering, and necrosis of the lower leaves. Thus, Havana was concluded to be a better experimental host than cvs. RP1 and TNN. Leaf symptoms developed as dark lesions surrounded by yellow margins and were observed after 80 to 120 days post inoculation. However, this time was shorter than that required (180 days) for CVC symptoms to develop in artificially inoculated citrus $(3,10,17)$.

Catharanthus roseus (Madagascar periwinkle) also has been used as an experimental host for $X$. fastidiosa strains $(6,20)$. The PD strains incited slight chlorosis in periwinkle but, even after 1 year, did not produce typical wilt and necrosis that the $X$. fastidiosa periwinkle strain induced (6). Periwinkle plants systemically infected with $X$. fastidiosa-CVC strains developed leaf deformation and stunting 2 months after inoculation, and disease symptoms developed for 4 months post inoculation to a severe leaf chlorosis (20). Periwinkle proved to be useful for investigating differential gene expression following infection with $X$. fastidiosa-CVC strains (20). However, compared with tobacco, periwinkle is not as amenable to transformation.

Mechanical inoculation of $X$. fastidiosaCVC strain in grapevines was reported to induce typical PD leaf scorch symptoms in seven commercial varieties of Vitis vinifera grown in Brazil and California (16). There are no reports of using $N$. tabacum as a bioassay or experimental host for other $X$. fastidiosa strains, such as those associated with PD and almond leaf scorch disease (ALSD) in California. Most strain characterization and pathogenicity assays rely on inoculation of susceptible grapevine $(V$. vinifera) and almond (Prunus amygdalus) cultivars. These woody hosts require from 2 to 4 months to express typical disease symptoms $(1,9,14,16)$. The lack of a good experimental host has been an obstacle for elucidating $X$. fastidiosa-host interactions and the molecular bases of $X$. fastidiosa pathogenicity and virulence.

Tobacco has been a model plant for studying transgenic traits prior to introducing the transgenes into agricultural crops. The full genome data of tobacco will be accessible in a short time through the Tobacco Genome Initiative of the North Carolina State University (http://www.tobacco genome.org). This effort is intended to 
promote the application of tobacco as a model system for gene expression, gene discovery, and studies in host-pathogen interaction.

The objective of this work was to develop and evaluate a tobacco bioassay for rapid, reliable confirmation of pathogenicity of $X$. fastidiosa strains to facilitate studies on $X$. fastidiosa-host interactions, as well as for testing potential anti-X. fastidiosa gene constructs.

\section{MATERIALS AND METHODS}

Bacterial strains and inoculum preparation. Bacteria used in the assays included $X$. fastidiosa strains Temecula, Traver, Stag's Leap, and Fetzer (kindly provided by A. H. Purcell) associated with PD of grapevines in California. A subculture of the PD-associated strain Temecula (kindly provided by B. Kirkpatrick), designated as Temecula-1, was used in these bioassays as a reference PD strain. Three strains of $X$. fastidiosa associated with ALSD in California, Dixon (kindly provided by A. H. Purcell) and two recently described almond strains, M12 and M23 (4), also were used. Bacterial strain stocks were stored in glycerol at $-80^{\circ} \mathrm{C}$ (to avoid loss of pathogenicity from successive passages) and were plated on PW medium solidified with Gel-Rite (PWG; 12) prior to the assay. For initial comparative assays, inoculum of $X$. fastidiosa strain Temecula1 was prepared from two types of cultures grown for 7 to 10 days at $28^{\circ} \mathrm{C}$ in liquid PW medium (5) shake cultures or on solid PWG medium. Cells were collected from the solid medium by washing the bacterial growth from plates with sterile, deionized water (SDW). Cell suspensions were centrifuged at $5,000 \times g$ for $10 \mathrm{~min}$ and washed twice in sterile deionized water. Cells were recovered from liquid culture by low-speed centrifugation at $5,000 \times g$ for $10 \mathrm{~min}$ and washed twice as above. For inoculation, aqueous suspensions of $X$. fastidiosa were standardized at 0.25 absorbance at $600 \mathrm{~nm}$, equivalent to approximately $2 \times 10^{8} \mathrm{CFU} / \mathrm{ml}$ (19). A modified Temecula1 strain, Gfp-KLN59.3 (22; kindly provided by S. Lindow), containing the fluorescent protein was used for inoculations to observe the colonization of tobacco xylem vessels by the bacterium by confocal laser scanning microscopy (CLSM).

Tobacco plants. Axenic N. tabacum plants were obtained from the Plant Transformation Facility of the University of California, Davis. Three easily transformable tobacco cultivars, Xanthi, Samsun NN, and SR1 (also called Petite Havana), were evaluated initially. Plants were maintained on one-half-strength Murashigue and Skoog minimal organic medium (Phyto Technology Laboratories, KS), containing sucrose at $15 \mathrm{~g} /$ liter (pH 5.6 to 5.8) and incubated at $25^{\circ} \mathrm{C}$ with a 12 -h photoperiod. Lighting was provided by cool fluorescent lights $(40 \mathrm{~W})$. Plants were subcultured every 4 weeks by removing the shoot tip and transferring to fresh medium in magenta boxes. Rooted plantlets (3 to $5 \mathrm{~cm}$ tall) with two to five basal leaves were transplanted into $10-\mathrm{cm}^{2}$ plastic pots containing soil mixture consisting of 1:1 ( $\mathrm{vol} / \mathrm{vol})$ Sunshine Mix Number 4 (Sun Gro Horticultural, Bellevue, WA) and Perlite coarse grade (Thermo-o-Rock, Chandler, AZ), pH 6.2, and transferred to a growth room with metal racks equipped with four high-intensity, 54-W fluorescent lights F54T5HO (GE, Fairfield, CT) located at approximately $70 \mathrm{~cm}$ above the shelves. The light intensity measured at the top foliage level $(20 \mathrm{~cm})$ was 6,000 lux. Plants were maintained at $28^{\circ} \mathrm{C}$ with a 12 $\mathrm{h}$ photoperiod. At 3 to 4 weeks after transplanting, and just before inoculation, plants were cut to 10 to $12 \mathrm{~cm}$ tall; only three fully or nearly fully expanded upper leaves were kept per plant, and the rest of the lower leaves were removed. In most cases, each plant was trained to a single new apical shoot that grew from the uppermost axil. However, multiple axillary shoots occasionally were allowed to grow during the post-inoculation assay period until the end of the assay ( 2 months) and after flowering.

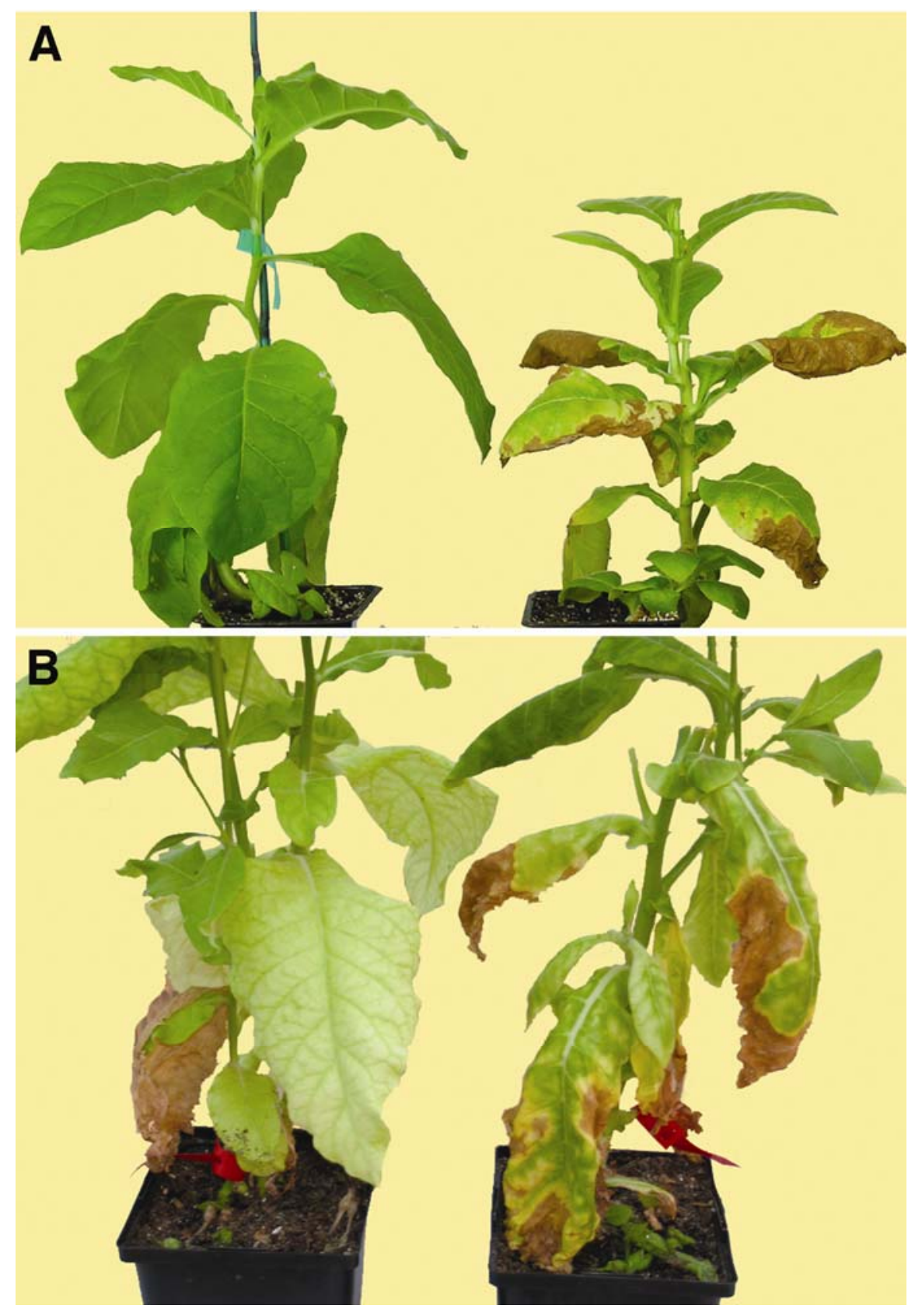

Fig. 1. Symptoms on Nicotiana tabacum cv. SR1 after inoculation with Xylella fastidiosa-Pierce's disease Temecula-1 strain. A, Fully developed symptoms 6 weeks after inoculation. Control plant mock inoculated with water (left) and plant inoculated with $X$. fastidiosa Temecula-1 (right). B, Advanced symptoms at flowering time ( 2 to 3 months after inoculation). Water mock-inoculated control plant showing normal leaf senescence (left) and $X$. fastidiosa-inoculated plant showing marginal leaf scorching and chlorotic halo around edge of scorch symptoms (right). 
Inoculation procedure. Three $20-\mu 1$ droplets of inoculum containing approximately $10^{8} \mathrm{X}$. fastidiosa cells $/ \mathrm{ml}$ were placed on a plastic petri dish surface. Each droplet was taken up with a 1-ml tuberculin syringe equipped with a $30 \mathrm{G}$ needle, and the entire volume was injected into the axils of a leaf. Three leaves per plant were inoculated. Plants similarly mock inoculated with water and noninoculated plants served as negative controls. To determine the specificity of the reaction, a set of plants was inoculated with Xanthomonas campestris pv. campestris. Plants were fertilized once a week with Peters General Purpose fertilizer 20-10-20 (Scotts-Sierra Horticultural Products, Marysville, $\mathrm{OH}$ ) at a concentration of $2 \mathrm{~g} /$ liter ( $\mathrm{N}$ at $21 \mathrm{ppm}$ ). Plants were kept in $10-\mathrm{cm}^{2}$ pots post inoculation and observed weekly.

Detection of Xylella fastidiosa. Samples were collected at 2-week intervals from Xylella fastidiosa-inoculated, Xanthomonas campestris pv. campestrisinoculated, mock-inoculated, and noninoculated tobacco plants. Leaves, as well as new shoots above the uppermost inoculation point, were analyzed for Xylella fastidiosa by double-antibody sandwich ELISA using a commercial kit for $X$. fastidiosa diagnosis following the manufacturer's instructions (Agdia, Elkhart, IN). Briefly, leaves were triturated (1:10, $\mathrm{wt} / \mathrm{vol})$ in extraction buffer $(0.5 \mathrm{M}$ Tris, $0.8 \% \mathrm{NaCl}, 2 \%$ polyvinyl-pyrrolidone 40,000, and $0.05 \%$ Tween 20, $\mathrm{pH} 8.2$ ). Mean absorbance values from duplicate wells that exceeded the background from extracts of noninoculated controls by three standard deviations were considered positive. Stem and petiole samples also were examined microscopically by transmission electron microscopy (TEM), scanning electron microscopy (SEM), and CLSM.

To determine differential colonization by the various strains, $X$. fastidiosa was isolated at the end of the assay ( 3 months
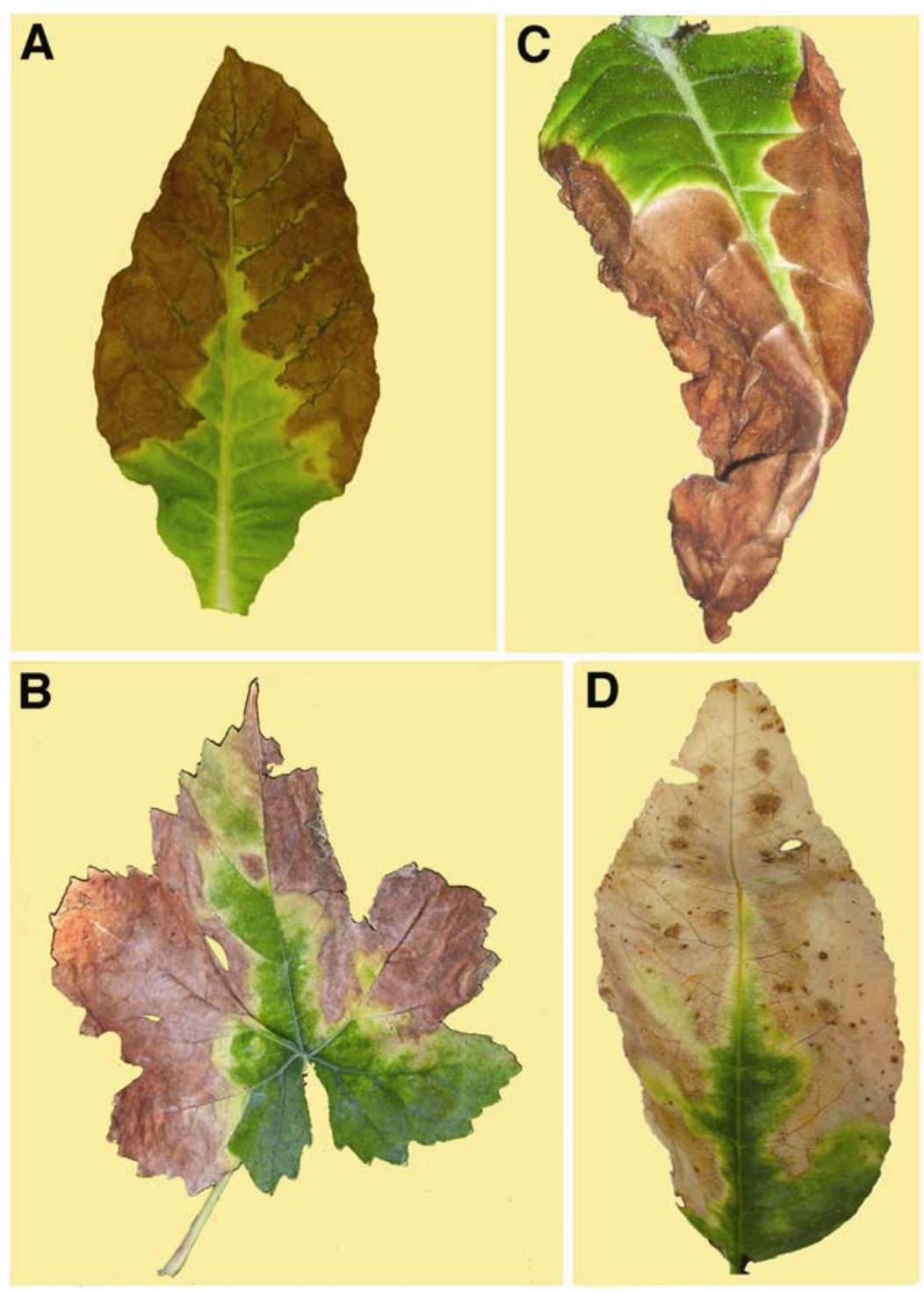

Fig. 2. Comparison of symptoms on Nicotiana tabaccum cv. SR1 inoculated with Xylella fastidiosaPierce's disease (PD) and $X$. fastidiosa-almond leaf scorch disease (ALSD) strains, and naturally $X$. fastidiosa-infected grapevine (PD) and almond (ALSD) plants. A, SR1 tobacco inoculated with $X$. fastidiosa-PD Temecula-1 strain. B, Naturally infected X. fastidiosa-PD grapevine leaf. C, SR1 tobacco inoculated with $X$. fastidiosa-ALSD Dixon strain. D, Naturally infected with $X$. fastidiosaALSD almond leaf.

Table 1. Detection and quantification of different Xylella fastidiosa strains in inoculated Nicotiana tabaccum SR1 plants ${ }^{\mathrm{a}}$

\begin{tabular}{|c|c|c|c|c|c|}
\hline Treatment & ELISA $^{\mathbf{b}}$ & $X$. fastidiosa isolation $^{c}$ & $\operatorname{QPRC}\left(C_{t}\right)^{d}$ & $X$. fastidiosa/g of tissue $\mathrm{e}^{\mathrm{e}}$ & Symptoms $^{\mathrm{f}}$ \\
\hline \multicolumn{6}{|l|}{ Pierce's disease strains } \\
\hline Temecula-1 & 9/9 & 9/9 & 21.8 & $4.3 \times 10^{7}$ & LS \\
\hline Fetzer & 9/9 & 9/9 & 19.5 & $1.5 \times 10^{8}$ & LS \\
\hline Traver & 9/9 & 9/9 & 20.5 & $9.3 \times 10^{7}$ & SLS, IVC, SG \\
\hline Stag’s Leap & $9 / 9$ & 9/9 & 20.4 & $1.0 \times 10^{8}$ & SLS, IVC, SG \\
\hline \multicolumn{6}{|l|}{ Almond leaf scorch disease strains } \\
\hline Dixon & 9/9 & 9/9 & 23.4 & $1.6 \times 10^{7}$ & LS \\
\hline M12 & $8 / 9$ & $8 / 9$ & 28.7 & $6.9 \times 10^{5}$ & ELC, LD \\
\hline M23 & $5 / 9$ & $5 / 9$ & 25.9 & $3.7 \times 10^{5}$ & ELC, LD \\
\hline \multicolumn{6}{|l|}{ Controls } \\
\hline Noninoculated & $0 / 9$ & $0 / 9$ & $\ldots$ & 0 & NS \\
\hline Water & $0 / 9$ & $0 / 9$ & $\ldots$ & 0 & NS \\
\hline Xanthomonas campestris pv. campestris & $0 / 9$ & $0 / 9$ & $\ldots$ & 0 & NS \\
\hline
\end{tabular}

a Summary of results of two independent assays with four and five plants per treatment.

b Number of enzyme-linked immunosorbent assay (ELISA)-positive plants/total number of plants inoculated.

${ }^{\mathrm{c}}$ Number of plants from which $X$. fastidiosa was isolated/total number of plants inoculated.

${ }^{\mathrm{d}}$ Quantitative polymerase chain reaction; values represent the mean cycle threshold $\left(\mathrm{C}_{\mathrm{t}}\right)$ of total positive plants essayed per treatment.

${ }^{\mathrm{e}}$ Number of $X$. fastidiosa cells estimated per gram of tobacco stems tissue.

${ }^{\mathrm{f}}$ Symptoms included normal senescence (NS), leaf scorch (LS), severe leaf scorch consisting of large ( $>50 \%$ of leaf blade) necrotic foliar areas and more than three leaves with leaf scorch symptoms (SLS), interveinal chlorosis (IVC), stunted growth (SG), extensive leaf chlorosis (ELC), and leaf drooping (LD). 
post inoculation). Plants were cut back to approximately $20 \mathrm{~cm}$ tall and a section of stem $(2 \mathrm{~cm}$ long) was excised from the top of the plant, disinfested by immersion in $70 \%$ ethanol for $1 \mathrm{~min}$ followed by $2 \mathrm{~min}$ in $0.5 \% \mathrm{NaOCl}$, and rinsed three times in SDW. The basipetal cut end of the stem section was trimmed and pressed with forceps onto the top of a 50- $\mu$ drop of SDW for 2 to $3 \mathrm{~s}$. This suspension $(10 \mu \mathrm{l})$ was diluted $1 / 20$ and $20 \mu \mathrm{l}$ of the diluted suspension was streaked onto the surface of PWG. The plates were incubated for 2 weeks at $28^{\circ} \mathrm{C}$ and evaluated for the presence of characteristic $X$. fastidiosa colonies. The identity of selected representative colonies was confirmed by PCR using primers set HL5/HL6 (7).

The pathogenicity of the $X$. fastidiosa Temecula-1 strain recovered from inoculated $N$. tabacum SR1 was confirmed by inoculation of self-rooted grapevine plants maintained in a greenhouse as previously described (15), using the table grape cultivar Ruby Seedless.

The presence of bacteria in xylem tissue of tobacco cv. SR1 and grape cv. Ruby Seedless inoculated with $X$. fastidiosa strain Temecula-1 was assessed by TEM and SEM. Petioles and stems from symptomatic infected plants were prepared for TEM using methods described in Hayat (11). Small pieces of tissue (1 to $2 \mathrm{~mm}^{3}$ ) were fixed with $6 \%$ glutaraldehyde in 0.05 $\mathrm{M}$ cacodylate buffer ( $\mathrm{pH}$ 7.2) for $24 \mathrm{~h}$ at $4^{\circ} \mathrm{C}$. The fixative solution was changed four times in the initial $2 \mathrm{~h}$. After three rinses in cold buffer, specimens were postfixed overnight with $2 \%$ osmium tetroxide at $4^{\circ} \mathrm{C}$, dehydrated in a graded series of acetone, and embedded in Spurr's resin (24). Ultrathin sections were cut with a diamond knife on a Leica Ultracut $\mathrm{R}$ ultramicrotome, double-stained with uranyl acetate and lead citrate, and then observed and photographed with an FEI Tecnai 12 TEM, operated at $120 \mathrm{kV}$.

Nicotiana and Vitis tissues were prepared for examination by SEM as described by Alves et al. (3), with minor modifications. Pieces of stem, petiole, and leaf midrib $5 \mathrm{~mm}$ long were fixed in $2.5 \%$ glutaraldehyde and $2.5 \%$ formaldehyde prepared from paraformaldehyde in $0.1 \mathrm{M}$ phosphate buffer ( $\mathrm{pH} 7.2$ ) for $24 \mathrm{~h}$ at $4^{\circ} \mathrm{C}$. Mild vacuum was applied to ensure the rapid infiltration of fixative into the specimens. The fixed specimens were washed in three changes of $0.1 \mathrm{M}$ phosphate buffer at $23^{\circ} \mathrm{C}$ for $0.5 \mathrm{~h}$ per change. The specimens were infiltrated overnight with a cryoprotectant, $30 \%$ glycerol in water. Specimens were plunge-frozen in liquid $\mathrm{N}_{2}$, then cross-sectioned with a scalpel blade. Specimens were postfixed in $1 \% \mathrm{OsO}_{4}$ in $0.1 \mathrm{M}$ phosphate buffer ( $\mathrm{pH}$ 7.2) for $1 \mathrm{~h}$, and then they were washed in three changes of deionized water for $0.5 \mathrm{~h}$ per change. The specimens were dehydrated in an ethanol series to $100 \%$ ethanol, then critical-point dried. The dried specimens were mounted on aluminum stubs and sputter-coated with gold. Observations and digital photos were made with a Hitachi S$3500 \mathrm{~N}$ SEM at $10 \mathrm{kV}$.

Tobacco leaves, previously inoculated with modified $X$. fastidiosa strain Temecula Gfp-KLN59.3 containing the fluorescent protein (21), were collected from plants immediately prior to examination by CLSM. Tobacco samples were prepared for microscopic examination by hand sectioning longitudinal sections with a razor. Sections were mounted in water on a glass slide and covered with a glass cover slip. Sections were examined with a Leica SP2 confocal laser scanning microscope. The samples were observed with a $\times 40$ oil immersion objective and the sections were excited with a 488-nm argon laser. The emission spectrum was collected in two channels, with the green fluorescent protein (GFP) in the 500- to 535-nm bandwidth and the auto fluorescence of the vessels in the 569- to 661-nm bandwidth. Images were digitally recorded using the Leica SP2 software.

Real-time PCR. Stem samples were taken $10 \mathrm{~cm}$ above the uppermost inoculation point (approximately $20 \mathrm{~cm}$ from the base). Stem pieces ( $2 \mathrm{~cm}$ long) were removed, disinfested successively in $70 \%$ ethanol for $1 \mathrm{~min}$ and $0.5 \% \mathrm{NaOCl}$ for 1 to $3 \mathrm{~min}$, and rinsed three times in SDW. A cross section ( 2 to $4 \mathrm{~mm}$ thick) was taken for nucleic acid extraction and real-time PCR (TaqMan) using primers HL5/HL6 and a probe labeled with FAM (7). After DNA extraction, samples were standardized at the equivalent of fresh initial tissue at $1 \mathrm{mg} / \mu \mathrm{l}$ of $0.5 \times$ Tris-EDTA buffer. PCR reactions were performed in $25-\mu l$ tubes with a Smart Cycler (Cepheid, Sunnyvale, CA). The concentration of $X$. fastidiosa was estimated from a standard curve relating cycle threshold $\left(\mathrm{C}_{\mathrm{t}}\right)$ to known concentrations of $X$. fastidiosa Temecula- 1 strain, ranging from 5 to $10^{5}$ cells per reaction $\left(C_{t}\right.$ 36 to $C_{t} 20$, respectively), with a coefficient of correlation $\left(R^{2}>0.97\right)(7)$.

\section{RESULTS}

Symptoms on tobacco. Preliminary tests were conducted in three independent assays with five replicate plants for each inoculation treatment to compare the responses of N. tabacum cvs. SR1, Xanthi NN, and Samsun to infection by $X$. fastidiosa PD strain Temecula-1. N. tabacum cvs. Xanthi NN and Samsun developed limited leaf chlorosis or necrosis (data not shown). N. tabacum cv. SR1 leaves developed stronger and more distinctive symptoms, characterized by laminar and marginal scorching surrounded by chlorotic haloes, than either Xanthi NN or Samsun. Therefore, SR1 was selected as the most suitable cultivar for further testing. In six independent assays using SR1, 28 of 30 $(93 \%)$ tobacco plants inoculated with Te- mecula- 1 and 8 of $10(80 \%)$ tobacco plants inoculated with strain Temecula GfpKLN59.3 developed leaf scorch symptoms. Both PD strains developed distinctive leaf scorch with chlorotic halo symptoms. The presence of $X$. fastidiosa in symptomatic and asymptomatic, systemically infected leaves was confirmed by ELISA (mean of absorbance at $492 \mathrm{~nm}$ for $X$. fastidiosa Temecula $=0.44$ and for Gfp-infected tobacco plants $=0.35$; noninoculated control plants mean $=0.08)$ and real-time $\mathrm{PCR}\left(\mathrm{C}_{\mathrm{t}}\right.$ range of infected plants 19 to 30 ).

Symptoms on leaves began as marginal chlorosis, followed by interveinal chlorosis 10 to 14 days after inoculation. Characteristic leaf scorch symptoms were observed 4 to 6 weeks after inoculation (Fig. 1A, right plant) and consisted of marginal necrosis surrounded by a bright yellow halo that delimited the necrotic area from healthy-appearing green tissue. Leaves on water-inoculated plants remained dark green (Fig. 1A, left). The systemic symptoms similar to those in the inoculated leaves extended to upper leaves, and remained up to the flowering time (Fig. 1B, right plant). New shoots were stunted and had small leaves that curled downward; necrotic streaks occurred in the stems of inoculated plants. Leaves on noninoculated and water-inoculated control plants senesced normally with a pale yellow discoloration of the entire leaf lamina and finally dried out (Fig. 1B, left plant). No symptoms were observed on plants inoculated with Xanthomonas campestris pv. campestris (data not shown).

The reactions of $N$. tabacum $\mathrm{cv}$. SR1 to inoculation with different Xylella fastidiosa-PD strains are presented in Table 1. X. fastidiosa-inoculated plants flowered 1 to 2 weeks earlier than those mock-inoculated with water and noninoculated plants. Systemic reactions were induced reproducibly by $X$. fastidiosa-PD strains Temecula-1, Fetzer, Stag's Leap, and Traver. More severe reactions were observed with $X$. fastidiosa-PD strains Stag's Leap and Traver than with strains Temecula-1 and Fetzer. Strains Stag's Leap and Traver caused severe dwarfing as well as smaller leaves that were puckered and curled downward, with extensive necrosis of the leaf blade. Necrotic streaks also were observed on the stems of inoculated plants.

All $X$. fastidiosa-PD strains produced leaf scorch symptoms in N. tabacum SR1 (Fig. 2A) that were similar to those that occurred in naturally PD-affected grapevines (Fig. 2B). Plants inoculated with $X$. fastidiosa-ALSD strains M12 and M23 developed chlorotic, drooping leaves that remained attached to the stem (Table 1). Tobacco inoculated with $X$. fastidiosaALSD strain Dixon developed leaf scorch symptoms (Fig. 2C) similar to those that occurred on leaves of naturally ALSDaffected almond trees (Fig. 2D). 

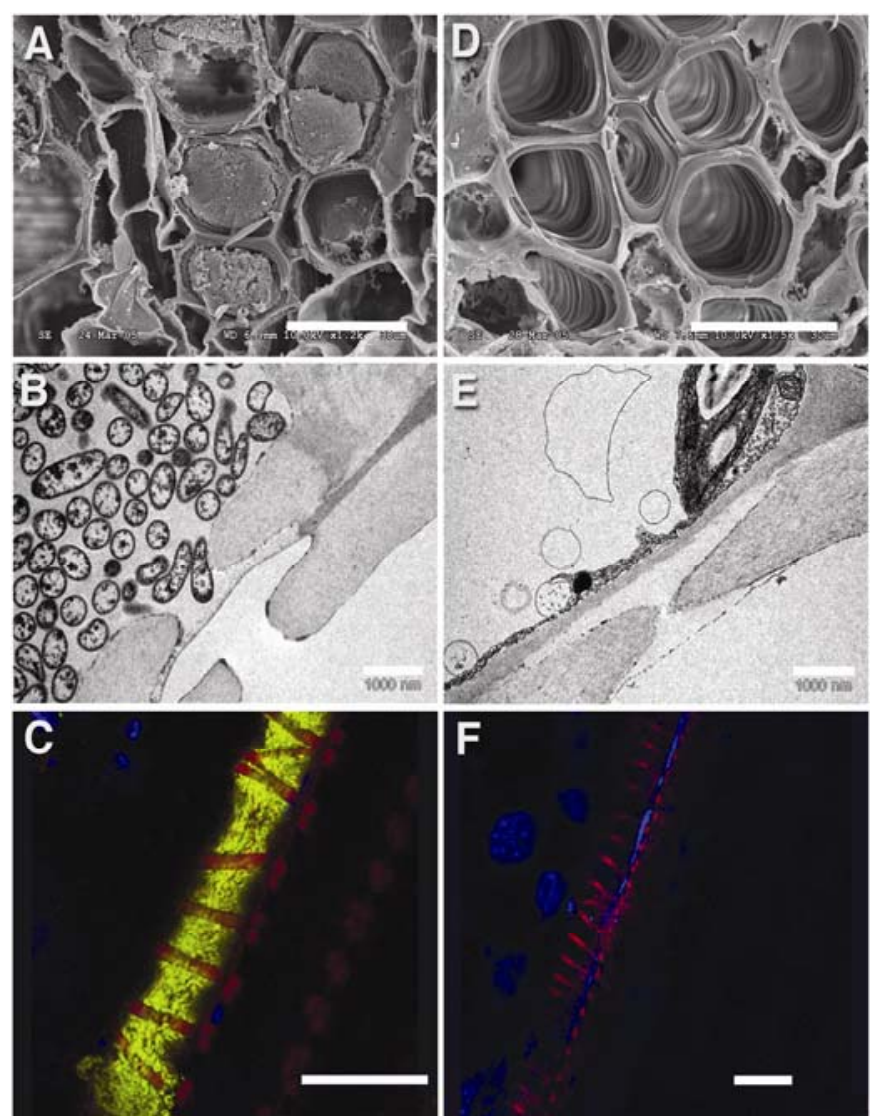

Fig. 3. Ultrastructure of petiole tissue of Nicotiana tabacum cv. SR1. A, Petiole tissue of plant inoculated with Xylella fastidiosa strain Temecula-1 observed in the xylem vessels by scanning electron microscopy (SEM). B, Similar tissue observed by transmission electron microscopy (TEM). C, Green fluorescent bacterial cells of X. fastidiosa (Gfp KLN59.3) strain observed in tobacco petiole using confocal laser scanning microscopy (CLSM). D, E, and F, Xylem vessels of control plants mock inoculated with water observed by SEM, TEM, and CLSM, respectively. Bars in A, B, C, and F equal $30 \mu \mathrm{m}$. Bars in B and E equal $1 \mu \mathrm{m}$.
Detection of $X$. fastidiosa. Bacteria were observed occluding xylem vessels of petioles, midveins, and stems of tobacco plants inoculated with $X$. fastidiosa strain Temecula-1 by SEM and TEM (Fig. 3A and B). $X$. fastidiosa cells of modified Temecula GfpKLN59.3 strain, containing the Gfp protein, were observed by CLSM (Fig. 3C) inside the xylem vessels of petioles and stems. No bacteria were observed in similar tissues from water-inoculated and noninoculated control plants (Fig. 3D, E, and F).

The presence of $X$. fastidiosa strains in affected plants was confirmed by reisolation of the pathogen, ELISA, and real-time PCR (Table 1). X. fastidiosa was not isolated from similar tissues from any of the negative control plants. ELISA and realtime PCR analyses of similar tissues from noninoculated and mock-inoculated control plants were negative for $X$. fastidiosa.

$X$. fastidiosa reisolated from $N$. tabacum cv. SR1 was inoculated into table grape cv. Ruby Seedless to confirm its pathogenicity. All inoculated grape plants developed distinctive leaf scorch (Fig. 4B) and typical "match stick" symptoms (Fig. 4C) described for PD (15). High levels of X. fastidiosa bacteria were observed in the xylem vessels of symptomatic leaf petioles from inoculated grapes by TEM (Fig. 4E). Therefore, $X$. fastidiosa retains pathogenicity after one passage in, and reisolation from, symptomatic $N$. tabacum cv. SR1 plants. No symptoms developed and no $X$. fastidiosa bacteria were found in waterinoculated controls (Fig. 4A and D).
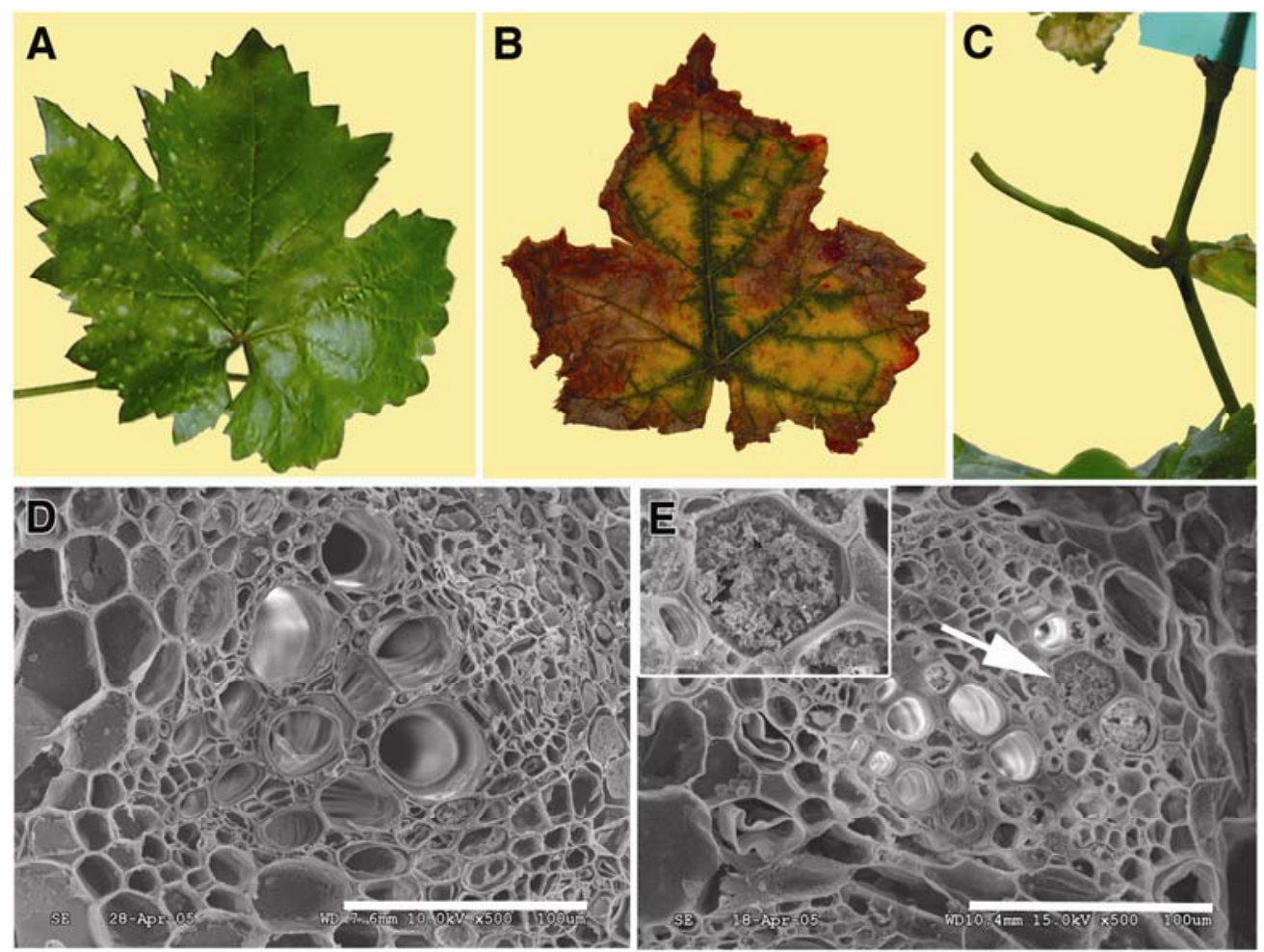

Fig. 4. Pathogenicity of the Xylella fastidiosa recovered from tobacco SR1 and reinoculated into grapevine plants. A, Ruby Seedless grapevine leaf from mock-inoculated water control. B, Leaf scorch symptoms developed on Ruby Seedless grapevines plants inoculated with $X$. fastidiosa-Pierce's disease (PD) strain Temecula-1 reisolated from SR-1 tobacco. C, 'Match sticks'symptom on stems of $X$. fastidiosa-infected grapevine. D, Ultrastructure of petioles observed by scanning electron microscopy from water mock-inoculated plants. E, Xylem vessel of grapevine inoculated with $X$. fastidiosa-PD (Temecula-1) strain recovered from infected, symptomatic tobacco. Bar represents $100 \mu \mathrm{m}$. Inset, magnification of xylem vessel completely plugged with $X$. fastidiosa. 
Quantification of $X$. fastidiosa populations in affected tobacco plants. Standard curves relating $\mathrm{C}_{\mathrm{t}}$ values to $X$. fastidiosa concentrations in real-time quantitative PCR (QPCR) were obtained using bacterial concentrations ranging from $10^{5} \mathrm{X}$. fastidiosa cells/mg of fresh tissue $\left(C_{t}=20\right)$ to $5 \mathrm{X}$. fastidiosa cells/mg of fresh tissue, the limit of detection $\left(\mathrm{C}_{\mathrm{t}}=36\right)$ (7). The estimated average $X$. fastidiosa populations per gram of stem tissue for PD-associated $X$. fastidiosa strains were $1.0 \times 10^{8}$ (Stag's Leap), $9.3 \times 10^{7}$ (Traver), $4.3 \times 10^{7}$ (Temecula-1), and $1.5 \times 10^{8}$ (Fetzer). Similarly, for ALSD-associated X. fastidiosa strains, these values were $1.6 \times 10^{7}$ (Dixon), $6.9 \times 10^{5}$ (M12), and $3.7 \times 10^{5}$ (M23).

\section{DISCUSSION}

Lack of a good experimental host has been an obstacle to studies of $X$. fastidios $a$-host interactions and to the identification of the molecular bases of the pathogenicity and virulence. Perennial $X$. fastidiosa hosts such as almond, grapevines, and citrus require extended and variable periods of time (e.g., 2 to 6 months) before symptoms are expressed $(1,2,10,14,15,17,18)$. Compared with experimental tobacco hosts evaluated previously, $X$. fastidiosa-inoculated SR1 tobacco appears to develop symptoms that are more like those seen for $X$. fastidiosainfected economic hosts and to develop those symptoms more rapidly. Previous research using tobacco as an experimental host for studying $X$. fastidiosa-host plant interactions was done with $X$. fastidiosa strains associated with CVC in Brazil $(3,17,18$, ) using, initially, native $N$. tabacum cv. RP1. X. fastidiosa-CVC strains induced small orange lesions on the leaves of inoculated tobacco plants. However, at least two inoculations were needed to obtain symptoms, and these were not observed until 80 days after the second inoculation. In addition, reisolation of $X$. fastidiosa was difficult due to presence of contaminants in the tobacco stems, and the pathogen was reisolated only from new shoots of these tobacco plants and only after the affected plants were cut back to $15 \mathrm{~cm}$ and allowed to regrow for an additional 60 days. The population of $X$. fastidiosa cells in these infected tobacco plants was estimated to be $4.9 \times 10^{4}$ to 6.6 $\times 10^{5} \mathrm{X}$. fastidiosa $\mathrm{CFU} / \mathrm{g}$ of tissue. Alves et al. (3) tested three additional tobacco cultivars: TNN, Havana, and RP1. In these tests, Havana expressed the most intense symptoms and was considered to be the best experimental host. Typical symptoms on Havana older leaves consisted of small dark lesions surrounded by yellow margins and were observed 75 days after severe pruning of the tobacco plants. The average titer of $X$. fastidiosa-CVC strains found in these plants was $10^{6} \mathrm{CFU} / \mathrm{g}$ of petiole tissue, using the plating method (3). Simi- lar titers of $3.2 \times 10^{5} X$. fastidiosa cells/g, as assayed by QPCR (22), were achieved in artificially $X$. fastidiosa-CVC-inoculated cv. Pera sweet orange at 8 to 12 months post inoculation.

We used conditions for SR1 tobacco culture that may be considered to be stressful; namely, growth in small $\left(10 \mathrm{~cm}^{2}\right)$ pots $(3,16), 28^{\circ} \mathrm{C}, 12 \mathrm{~h}$ of high-intensity light, and weekly fertilization. Similarly, Lopes et al. (18) found that young citrus seedlings grown in small trays developed higher rates of infection than seedlings grown in larger pots. Our conditions resulted in rapid development of a distinct chlorosis of leaves for the X. fastidiosainoculated SR1 plants, contrasting with the normal dark green foliage of control plants. The tobacco bioassay reported here employed tissue culture-derived plants. These have several advantages over the use of seedlings, including uniform and more vigorous plants that are easily conserved and available at any time of the year. Tissue culture plants do not show the juvenile characters of plants reproduced by seed, the stems are thicker, and the leaves are bigger and easy to handle for inoculation. The use of controlled environment was found to be advantageous compared with greenhouse or field assays. Under optimal growth conditions, including high-intensity light, controlled temperature, and appropriate fertilization, distinctive expression of symptoms was more consistent and reproducible.

Under our conditions, $N$. tabacum genotype SR1 developed severe symptoms 4 to 6 weeks after inoculation. Symptoms were similar to those observed on grape and almond affected by PD and ALSD, respectively. For PD-associated and ALSDassociated X. fastidiosa strains, QPCRassessed titers in SR1 tobacco stem tissue ranged between $4.3 \times 10^{7}$ and $1.5 \times 10^{8} \mathrm{X}$. fastidiosa cells/g and between $6.9 \times 10^{5}$ and $1.6 \times 10^{7} X$. fastidiosa cells/g, respectively. Based on colony counts of $X$. fastidiosa reisolated from an inoculated plant, SR1 tobacco supported ALSD strain Dixon at $10^{7} \mathrm{CFU} / \mathrm{g}$ and ALSD strains M12 and $\mathrm{M} 23$ at $10^{5} \mathrm{CFU} / \mathrm{g}$. For comparison, $X$. fastidiosa titers reported in California were $10^{8}$ to $10^{9} \mathrm{CFU} / \mathrm{g}$ for PD-affected grapevine and $<10^{7} X$. fastidiosa cells/g for ALSD-affected almond (1). Similarly, QPCR detected, per gram of fresh weight tissue, the equivalent of $10^{7}$ to $10^{8}$ cells for PD-affected grapevine and $10^{6}$ to $10^{7}$ cells for ALSD-affected almond (7). Thus, $X$. fastidiosa ALSD strains generally reach lower titers in infected plants than $X$. fastidiosa PD strains achieve, and there is a correlation between $X$. fastidiosa titers in SR1 tobacco and in grapevine and almond, suggesting that $X$. fastidiosa virulence of these strains in SR1 tobacco reflects the virulence of $X$. fastidiosa PD and ALSD strains in their economic hosts. Genotype SR1 N. tabacum is readily transformed and should be useful for analyzing $X$. fastidiosa mutants with altered pathogenicity, transgenes whose expression may alter the course of infection and disease development, and other important aspects of $X$. fastidiosa-plant interactions.

\section{ACKNOWLEDGMENTS}

This work was supported by a Specific Cooperative Agreement between the United States Department of Agriculture-Agricultural Research Service (USDA-ARS) and the University of California, Davis, and by the California Department of Food and Agriculture Pierce's Disease Control Program, award 2006-67. We thank E. Farkas (USDA-ARS, Parlier, CA) for technical assistance; B. Kirkpatrick and P. Ronald (University of California, Davis), A. H. Purcell and S. E. Lindow (University of California, Berkeley), and J. C. Chen (USDA-ARS, Parlier, CA) for providing bacterial strains; D. Tricoli (Ralph M. Parsons Plant Transformation Facility, University of California, Davis) for providing the initial Nicotiana tabacum plants in vitro; D. Hoffmann, D. Margosan, and R. Emershad (USDAARS, Parlier, CA) for assistance in the TEM, SEM samples, and tissue culture techniques, respectively; P. Houston Joost (Department of Entomology, University of California, Riverside) for providing the CLSM images; and L. W. Timmer (University of Florida, CREC) for the review of the manuscript.

\section{LITERATURE CITED}

1. Almeida, R. P. P., and Purcell, A. H. 2003. Biological traits of Xylella fastidiosa strains from grapes and almonds. Appl. Environ. Microbiol. 69:7447-7452.

2. Almeida, R. P. P., and Purcell, H. A. 2003 Homoladisca coagulata (Hemiptera: Cicadellidae). Transmission of Xylella fastidiosa to almond. Plant Dis. 87:1255-1259.

3. Alves, E., Kitajima, E. W., and Leite, B. 2003. Interaction of Xylella fastidiosa with different cultivars of Nicotiana tabacum: a comparison of colonization pattern. J. Phytopathol. 151:500-506.

4. Chen, J., Groves R., Civerolo, E. L., Viveros, M., Freeman, M., and Zheng, Y. 2005. Two Xylella fastidiosa genotypes associated with almond leaf scorch disease on the same location in California. Phytopathology 95:708-714.

5. Davis, M. J., French, W. J., and Schaad, N. W. 1981. Isolation and culture of the bacteria associated with phony peach disease and plum leaf scald. Phytopathology 71:869-870.

6. Davis M. J., Raju, B. C., Brlansky, R. H., Lee, R. F., Timmer, L. W., Norris, R. C., and McCoy, R. E. 1983. Periwinkle wilt bacterium: Axenic culture, pathogenicity and relationships to other gram-negative xylem-inhabiting bacteria. Phytopathology 73:1510-1515

7. Francis, M., Lin, H., Cabrera-La Rosa, J. C., Doddapaneni, H., and Civerolo, E. L. 2006. Genome-based primers for specific and sensitive detection and quantification of Xylella fastidiosa. Eur. J. Plant Pathol. 115:203-213.

8. Gould, A. B., and Lashomb, J. H. 2005. Bacterial leaf scorch of shade trees. Online APSnet Feature story. November 2005. http://www. apsnet.org.

9. Guilhabert, M. R., and Kirkpatrick, B. C. 2005. Identification of Xylella fastidiosa antivirulence genes: Hemagglutinin adhesins contribute to $X$. fastidiosa biofilm maturation and colonization and attenuate virulence. Mol. Plant-Microbe Interact. 18:856-868.

10. Hartung, J. S., Beretta, J., Brlansky, R. H., Spisso, J., and Lee, R. F. 1994. Citrus variegated chlorosis bacterium: axenic culture pathogenicity, and serological relationships with other strains of Xylella fastidiosa. Phytopathology 84:591-597. 
11. Hayat, M. A. 2000. Principles and Techniques of Electron Microscopy: Biological Applications, 4th ed. Cambridge University Press, New York.

12. Hill, B. L., and Purcell, A. H. 1995. Acquisition and retention of Xylella fastidiosa by an efficient vector, Graphocephala atropunctata. Phytopathology 85:209-212.

13. Hopkins, D. L., and Purcell, A. H. 2002. Xylella fastidiosa: Cause of Pierce's disease of grapevine and other emergent diseases. Plant Dis. 86:1056-1066.

14. Krivanek, A. F., Stevenson, J. F., and Walker, M. A. 2005. Development and comparison of symptom indices for quantifying grapevine resistance to Pierce's disease. Phytopathology 95:36-43.

15. Krivanek, A. F., and Walker, M. A. 2004. Vitis resistance to Pierce's disease is characterized by differential Xylella fastidiosa populations in stems and leaves. Phytopathology 95:44-52.

16. Li, W. B., Zhou, C. H., Pria, W. D., Jr., Texeira, D. C., Miranda, V. S., Pereira, E. O., Ayres, A.
J., He, C. X., Costa, P. I., and Hartung, J. S. 2002. Citrus and coffee strains of Xylella fastidiosa induce Pierce's disease in grapevine. Plant Dis. 86:1206-1210.

17. Lopes, S. A., Ribeiro, P. G., Franc, S. C., and Santos, J. M. 2000. Nicotiana tabacum as an experimental host for the study of plant-Xylella fastidiosa interactions. Plant Dis. 84:827-830.

18. Lopes, S. A., Texeira, D. C., Fernandez, N. G., Ayres, A. J., Torres, S. C. Z, Barbosa, J. C., and Li, W. B. 2005. An experimental inoculation system to study citrus Xylella fastidiosa interactions. Plant Dis. 89:250-254.

19. Minsavage, G. V., Thompson, C. M., Hopkins, D. L., Leite, R. M. V. B. C., and Stall, R. E. 1994. Development of a polymerase chain reaction protocol for detection of Xylella fastidiosa in plant tissue. Phytopathology 84:456461.

20. Monteiro, P. B., Renaudin, J., JagoueixEveillard, S., Ayres, A. J., Garnier, M., and Bové, J. 2001. Catharanthus roseus, an experimental host plant for the citrus strain of
Xylella fastidiosa. Plant Dis. 85:246-251.

21. Newman, K. L., Almeida, R. P. P., Purcell, A H., and Lindow, S. E. 2003. Use of a green fluorescent strain for analysis of Xylella fastidiosa colonization of Vitis vinifera. Appl. Environ. Microbiol. 69:7319-7327.

22. Oliveira, A. C., Vallim, M. A., Araujo, W. L. Goldmann, G. H., and Machado, M. A. 2002 Quantification of Xylella fastidiosa from citrus trees by real-time polymerase chain reaction assay. Phytopathology 92:1048-1054.

23. Purcell, A. H., and Hopkins, D. L. 1996. Fastidious xylem-limited bacterial plant pathogens. Annu. Rev. Phytopathol. 34:131-151.

24. Spurr, A. R. 1969. A low-viscosity epoxy resin embedding medium for electron microscopy. J. Ultrastruct. Res. 26:31-43.

25. Wells, J. M., Raju, B. C., Hung, H. Y., Weisburg, W. G., Mandelco-Paul, L., and Brenner, D. J. 1987. Xylella fastidiosa gen. nov., sp. nov. gram-negative, xylem-limited, fastidious plant bacteria related to Xanthomonas spp. Int J. Syst. Bacteriol. 37:136-143. 